\title{
Decisiveness and Inclusiveness: Two Aspects of the Intergovernmental Choice of European Voting Rules
}

\author{
Thomas König and Thomas Bräuninger \\ Universität Konstanz, Fachbereich Politik- und Verwaltungswissenschaft, D-78457 Konstanz, \\ Germany,E-mail: t.koenig@uni-konstanz.de.
}

Abstract: When studying the constitutional choice of European voting rules, most power index analyses concentrate on member states' relative decisiveness for forming winning coalitions in the Council of Ministers. These studies have two shortcomings: (a) They ignore the distribution of relative power between the Commission, the Council of Ministers and the European Parliament, as defined by the multi-cameral European legislative procedures. (b) They disregard the absolute notion of power, which is dependent on the inclusion of member states in winning coalitions under various voting rules. In this article we present our approach on member states' constitutional choice of European voting rules with regard to the two notions of power: actors' relative decisiveness and their absolute inclusiveness in decision making. We present an index to measure inclusiveness and apply our concept to the European multi-cameral legislature. On the basis of our study, we present a reasoned account of motives behind member states' recent institutional reforms of legislative procedures.

\section{The constitutional change of European voting rules}

Constitutional events have recently changed the voting rules of the European (EU) legislature. Since the mid 1980s, Treaty reforms such as the Single European Act in 1987, the Maastricht Treaty in 1993 and the accession of Portugal and Spain (1986) and of Austria, Finland and Sweden (1995) have brought about continued modification to EU voting rules. To study this constitutional change two prominent measurement concepts are applied: the cooperative intergovernmental power index and the non-cooperative spatial model approach. Under the cooperative assumption of binding and enforceable agreements, the power index approach concentrates on different voting rules and the effects of accession scenarios. It reduces the phenomenon of Treaty reform to the question of how the distribution of voting weights in the Council of Ministers determines the distribution of power between member states. 
The non-cooperative spatial model approach studies the strategic interaction between the Commission, the Council and - in some cases - the European Parliament (EP). Based on actors' spatial preferences, these models focus on the choice within rules in a uni- or multi-dimensional policy space. With regard to EU decision making their application reveals the strategic interaction between different voting bodies. Except for Article 148, 2b, all EU legislative procedures require a Commission proposal that must be adopted by the member states with unanimity, simple or qualified majority. Since most voting power studies have ignored the interaction between EU voting bodies, the spatial model approach calls their utility fundamentally into question (Garrett/Tsebelis, 1996, 270). The application of spatial models, however, underestimates certain formal voting differences between member states, voting weights for example, when studying the impact of various EU decision-making procedures instead of the impact of member states' constitutional choice.

In this paper we argue that both approaches have so far failed to give a satisfactory account of the complexity of the EU institutional framework. When member states make a constitutional choice, they decide on the application of voting rules for EU legislation without knowing their own and others' spatial preferences on future legislative proposals (Buchanan/Tullock, $1962,78)$. This is the major difference between the choice within and the choice of voting rules. Intergovernmental power index analyses assume that the configuration of member states' voting weights in the Council of Ministers sufficiently explains the constitutional choice of voting rules in the expanding community (Brams/Affuso, 1985; Hosli, 1993; Johnston, 1995; Widgrén, 1994; Lane et al., 1995). If some actors are privileged with higher voting weights or individual veto rights, relative voting power studies calculate their formal prerogatives by their relative abilities of being decisive in forming winning coalitions. We call this element of constitutional choice analysis relative decisiveness, describing one property of voting rules, namely the distribution of expected gains from future decision making.

Yet, relative decisiveness does not reveal the second property of voting rules. According to this concept, all member states have the same relative power under siple majority, qualified majority and unanimous voting in the case of "One-Man-One-Vote" provisions (König/Bräuninger, 1998, 136). Though weak simple majority voting increases the power to act of the voting body as a whole, unanimity requires the inclusion of all actors, thus leading to a high status quo bias (Buchanan/Tullock, 1962; Coleman, 1971). As the introduction of majority rules entails the possible exclusion of an actor, the crucial question is whether a member state accepts the possibility of being in a minority position in future EU legislation. In order to measure this second 
property of voting rules we introduce our concept of absolute inclusiveness describing the amount of expected gains from future decision making.

Our concern is the description of both aspects of power for the various EU procedures. In our view, member states choose specific voting rules to allocate power in order to obtain a (fair) distribution of legislative gains. We argue that the combination of both relative decisiveness and absolute inclusiveness reveals the allocation of power for specific policy areas. Relative decisiveness is understood as reflecting the actors' chances of determining the legislative outcome. Member states provide themselves with shares of votes to make a distribution of legislative gains they have agreed upon possible. Inclusiveness, however, refers to the possible number of decisions dependent on the strength of the voting rule. Both concepts are related to the member states' expectations of EU legislative gains, determining their constitutional choice of either unanimity, qualified majority, simple majority, or single veto players for specific policy areas.

In addition to previous voting power studies we not only take into account the power to act of the voting body as a whole but also the interaction between EU voting bodies. For this purpose we formulate inter-institutional sets of winning coalitions consisting of the Commission, members of the Council and - sometimes - of the EP. The remainder of this article is divided into three sections. In section 2 we present our concept of acting entities and the inter-institutional set of winning coalitions. Thereafter, we introduce the indices on relative decisiveness and absolute inclusiveness. Finally, we apply both measures on current EU legislative sets of winning coalitions.

\section{Acting entities and inter-institutional sets of winning coalitions}

The concept of legislative winning coalitions is a fundamental element of the game-theoretical measurement of legislative entities' decisiveness and inclusiveness. Referring to the assumption on methodological individualism, both measures presuppose the identification of relevant actors and their procedural interaction. In the past, the identification problem of EU winning coalitions was often falsely trivialised. This trivialisation found its expression in the ignoring of inter-institutional interaction, the assumption of a unitary (parliamentary) actor, or the disregard of actors' voting weights. We intend to improve the reliability of our approach by presenting our concept of EU actors and EU procedural interaction (Figure 1).

In game-theoretical analyses, actors are simply defined as entities making choices in a specific context. This definition first presumes the identification of the acting entities and then considers the qualification of goal 
specificity, independence and consistence for their actions. In international relations theory, the unitary actor assumption of state behaviour is an illustrative example for the ongoing debate on the identification problem of acting entities (Achen, 1995). In the field of power index analysis the primary task of actually identifying the relevant legislative entities is a well-known problem. "Paradoxes" like the paradoxes of quarrelling members, of new members and of size (Brams, 1975), or the paradox of redistribution (Fischer/Schotter, 1978) illustrate some of the crucial effects on relative decisiveness when either the set of entities, or the entities themselves, are modified.

Type of actors

Level of game

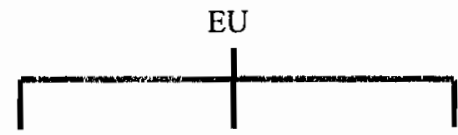

Compound game

Collective Commission

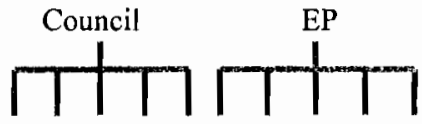

Subgame

Corporate

Member states Political groups

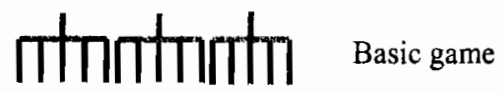

Individual

Representatives

Figure 1. EU legislative game

To avoid identification problems, we begin our analysis by distinguishing between three types of legislative entities: individuals (natural persons), corporate actors (organisations with delegates as their agents), and collective actors (voting bodies). Like a natural person, a corporate actor is often considered to be a unitary entity having well-behaved preferences over outcomes and acting on purpose. Hence, there is no difference between individual and corporate actors if we ignore the controlling problem of delegates. In contrast to individual and corporate actors, collective actors are analysed as aggregates of individuals and/or corporate actors. The aggregation problem of individual and/or corporate actors is the topic of social choice theory. Studies in this area show that the unitary actor assumption on collective actors rarely applies in cases of two or more preference dimensions (McKelvey, 1979; Koehler, 1990).

In EU legislation all three types of actors are relevant. Commission, Council and EP are voting bodies aggregating different sets of legislative entities. The Commission prepares proposals on which most of EU legislative decisions are based. In principle, the Commission is a college of twenty 
Commissioners each responsible for his or her General Directorate. Each Commissioner is provided with his or her own portfolio, carries the main leadership responsibility, and is independent of the Commission President in determining how to act on EU legislative decisions. We therefore conceptualise the Commission as a unitary actor in EU legislation with the responsible Commissioner as its agent (see also Spence, 1994; Westlake, 1994).

In the Council, the governments of the member states are represented by delegates mediating between their own governments and those of other delegates (Johnston, 1994). National governments instruct their delegates, who then cast their votes homogeneously in the Council. Since we ignore the controlling problem of delegation, we conceptualise the national delegate as an entity voting for its member state. Regarding the member states' votes, we can distinguish between equal and unequal settings. In the case of the EU qualified majority rule with $71,2 \%$ voting quota, voting weights differ between large and smaller member states, thus providing for unequal settings. Against this, equal settings are provided for by the simple majority criterion and unanimity where member states are counted one-country-onevote. Member states' votes are then aggregated in the Council, a collective actor facing other voting bodies in the course of EU legislative decision making.

Although the EP is less involved in EU legislative decision making, the disaggregation of the EP's entities causes further conceptual difficulties. Apart from different combinations of formal institutional settings, parliamentary systems differ in terms of specific peculiarities characteristic of a particular legislature. A specific characteristic of the EP is the affiliation of parliamentary representatives to both political and national groups. The fact that the vote of EP representatives on national group affiliation is merely a repetition of the intergovernmental, state-versus-state conflict in the Council, means that it is the political group affiliation that points out the unique contribution of parliamentary participation in EU legislation. We model political groups as EP entities with votes weighted according to their party representatives on the grounds that party cleavage is observed to dominate over national cleavage in the formation of majority coalitions (Jacobs et al., 1992; Attina, 1990). Since no political group has an absolute majority at its disposal, political group votes are, by empirical necessity, aggregated in the EP.

The varying voting rules in the Council and the EP reveal different levels of EU legislation. We can distinguish between three levels: the basic game, the subgame, and the compound game. The basic game refers to the prime entities such as individuals or national party delegations which form the political groups in the EP. On the subgame level, the internal coalition problem of the member states in the Council and the parliamentary political groups in the EP has to be solved. Except for constitutional unanimity, the 
Council subgame offers two voting criteria, since, even in the case of majority voting, amendments always require unanimity among member states. Under the cooperation and codecision procedures, the EP may take action or no action. Preventing endorsement by no action slightly decreases the majority criterion, since - as the EP has always been a voting body consisting of an equal number of representatives - 50 per cent of all votes are sufficient to prevent action while taking action needs 50 per cent plus one votes.

Finally, the procedural settings of EU legislation define legislative sets of winning coalitions consisting of all entities necessary to adopt a proposal. ${ }^{\prime}$ However, identifying EU inter-institutional sets of winning coalitions is made rather more complicated for two reasons: First, the Council and the EP's voting rules vary, and second, the role of the Commission is rather speculative. According to Article 155, the Commission holds the exclusive right to initiate legislation and the right to modify a proposal at any point of procedure (Article 189a, 2), thereby making the Commission the agenda setter. Moreover, the Commission also has the right to withdraw, if the proposal's original object is felt to have been emasculated by amendments (Usher, 1994). The Commission cannot, therefore, be excluded from the set of all relevant legislative entities.

Legislative sets of winning coalitions represent the cornerstone of our analysis of EU legislative entities' decisiveness and inclusiveness. With regard to the fact that member states establish different legislative sets by introducing different procedures for EU policy areas, we investigate the reasons for member states making the choices for specific institutional settings that they do. We take into account the arguments of spatial analysts on the importance of actors' policy preferences by means of our inclusiveness index. In addition, we apply the relative decisiveness concept to the interinstitutional sets of winning coalitions in EU legislation. In the following

${ }^{1} \mathrm{EU}$ legislative sets of winning coalitions require consent among all relevant voting bodies and thus depend on the solution of the coalition problems at the subgame level. Winning coalitions of the bicameral standard procedure require the consent of the Commission and of the Council referring to unanimity, simple or qualified majority subgames of member states. The semi-tricameral cooperation procedure includes the EP in EU legislation in one out of two sets of feasible winning coalitions: the first set encompasses the Commission and all member states, the second set consists of coalitions comprising the Commission, more than 62 Council votes and at least half of the EP votes. The latter set of winning coalitions is also feasible under codecision procedure, but in this case the second set combines the unanimous member states with at least the absolute majority of EP votes. Since the Commission no longer has the right to withdraw its proposal when Council and Parliament conciliate their views in the second reading of the codecision procedure, the Commission can be excluded. Hence, under codecision procedure the EP holds the same position as the Commission under cooperation procedure. In this respect, both combinations of the two sets of winning coalitions install a semi-tricameral system: either the EP or the Commission can be excluded from EU legislation. 
section we argue that member states take into account the effects on both their decisiveness and their inclusiveness when they introduce or change the procedural settings for EU policy areas.

\section{Decisiveness and inclusiveness in European legislation}

The bicameral setting of the standard procedure between the Commission and the Council and the semi-tricameral participation of the EP under cooperation and of the Commission under codecision procedure suggest that member states try to reach different goals by Treaty reform, such as reducing EU transaction costs or decreasing the so-called democratic deficit (see Wessels, 1991; Ludlow, 1991). In the past, Treaty reforms have given the Commission functions of legislative agenda setting and safeguarding, and the EP more rights in EU legislation. However, since the member states are the signatories of the EU constitution, we argue that their expected gains are the driving force behind the material integration of policy areas and the constitutional choice of different procedures. Thus, by focusing solely on the impact on qualified majority rule in the Council, many intergovernmental analyses are unable to provide insight on the reasons for institutional delegation.

This shortcoming is best illustrated by some of the partly striking, then again partly insufficient conclusions drawn from such voting power calculations. The most prominent result was the discovery of the "dummy playerposition" of Luxembourg. According to relative voting power analysts, Luxembourg therefore did not realise the fact that it would have no relative power during the first EU Treaty era under qualified majority rule (Brams, 1976). Second to this, Council power index analysis recently claimed to have "uncovered" the unfavourable British attitude towards the blocking minority rule, as the proposed increase from 23 to 26 minimum votes would reduce the British relative power share (Johnston, 1995). Others argue that, due to the accession of new members, the relative decisiveness differences between unanimity and majority voting rules become less and less pronounced (Lane et al., 1995). Such striking conclusions prompt the question of whether member states actually misperceive the impact of Treaty reform or whether the study of relative decisiveness is an insufficient tool for explaining intergovernmental choice of EU voting rules (Garret et al., 1995).

On closer inspection, indices on relative decisiveness are calculated using the concept of simple games with two properties: First, simple games only differentiate between winning and losing coalitions; and, second, they satisfy monotonicity assuming the continuance of a winning coalition in 
cases of additional members. ${ }^{2}$ In the case of simple games, indices of relative decisiveness are single valued solution concepts on pivotal entities. Being pivotal can be interpreted as being a relative resource resulting from the entities' probability of realising their preference in the collective outcome. If member states have different voting weights under majority rule, these resources can be distributed asymmetrically. However, since member states make their constitutional decision on Treaty reform under unanimity, the question is why a member state should accept a higher voting weight of another member state providing the latter with more relative resources for future majority decision making.

In our view the constitutional choice of EU voting rules depends on the expected gains from potential legislation which are determined by both the number of feasible decisions and the distribution of their gains. When reforming the EU framework, member states' central motive is to improve their gains from future legislation based on their expected profits minus their expected costs of potential EU legislation. According to Buchanan/Tullock $(1962,70)$, signatories decrease the voting quota when all incumbents expect higher gains from future majority legislation. Accordingly, if member states expect to be affected similarly by future legislation, they establish the "OneMan-One-Vote" provision providing for a uniform distribution of expected gains. Consequently, different voting weights are established to obtain a balanced distribution of EU legislative gains if the status quo or the expected decision affect member states differently. For example, the unification of Germany had no effect on the distribution of member states' voting weights because the latter serve as a parameter for the distribution of expected gains rather than for the representative size of the member states' population.

Voting weights, minority blocking rules, veto player positions or multicameralism with different subgames are all methods of balancing the distribution of expected gains. Despite their procedural variety, all these methods may differentiate between the entities' relative ability of being decisive on any EU legislative proposal. Though relative power index analysis is widely used, its application on EU inter-institutional sets of winning coalitions imposes severe demands on the method of measurement. Compared to unicameral analysis, the normalisation over all entities must appropriately reflect the conditions for the different levels, the basic games, the subgames and the inter-institutional compound game (König/Bräuninger, 1996, 338). Taking this into consideration, the most applicable concepts for the analysis of the relative decisiveness of entities in inter-institutional sets of winning 
coalitions are arguably the normalised Banzhaf and the Shapley-Shubik index (Nurmi, 1987).

Although both indices have certain theoretical parallels, they differ with respect to their conceptions of critical defections. An entity's relative contribution to transforming winning into losing coalitions determines the relative Banzhaf power (Banzhaf, 1965). In particular for inter-institutional sets of winning coalitions, the additivity of these critical positions must be called into question, since the Banzhaf index takes into account several critical positions in one single winning coalition (Dubey/Shapley, 1979). This raises the question of how to interpret Banzhaf additive power, because highly vulnerable minimal winning coalitions become more important for the power calculation than those only made vulnerable by a few members (Shelley, 1986). For this reason, the inter-institutional relationship of Banzhaf decisiveness is highly distorted by the different membership size of EU voting bodies. The Shapley-Shubik index refers to all possible voting sequences and checks how often each entity is able to transform a losing into a winning coalition (Shapley/Shubik, 1954). An entity's decisiveness is defined as the probability of being pivotal, i.e. decisive in one of all equal probable voting sequences. Based on this probability concept, the individual Shapley-Shubik shares, $\phi_{i}$, can be added up over any set of actors and be interpreted as an additive measure for relative coalitional power. We therefore apply the Shapley-Shubik index to measure individual decisiveness.

We regard relative decisiveness as being one major aspect of member states' constitutional choice. Following the same line of thought, we consider their choice of the strength of a voting rule to be the second major aspect of EU institutional integration because it influences the likely policy outcomes that will ensue. Weak voting rules, like simple majority, increase the number of feasible decisions by facilitating the possible exclusion of entities from the EU legislative set of winning coalitions, whereas unanimity guarantees high inclusiveness for all actors, resulting in a high status quo bias of single favourable winning coalitions. The rationale for member states' choice of unanimity rule might therefore be an expectation of low legislative gains either because of low profits or high costs. Accordingly, member states only expose themselves to the danger of exclusion if they expect higher profits from future EU legislation.

The strength of a voting rule refers to the entities' chances of being included in any potential decision. Since we assume Yes- and No-votes to have the same probability, all feasible coalitions are equiprobable. In simple games, the probability of an entity's inclusion varies between 0.5 and 1.0 . Strong voting rules guarantee the inclusion of an entity's preferences in the collective decision, whereas the inclusion of an entity's preference is determined by luck if it can be excluded from any feasible winning coalition 
(Barry, 1989, 287). Thus, the inclusiveness of a dummy player is still 0.5 . Assuming $v$ to be a simple game, where $v(S)=1$ if $S$ is winning, we define the inclusiveness index $\omega$ of actor $i$ in the game $v$ as

$$
\omega_{i}(v)=\frac{\sum_{S \subseteq N, i \in S} v(S)}{\sum_{S \subseteq N} v(S)},
$$

i.e. $i$ 's number of participations in winning coalitions in relation to the number of all feasible winning coalitions (Bräuninger, 1996).

Neither the relative nor the absolute aspect of voting power solely describe the choice of voting rules. In our view, voting rules are instruments that can be used to obtain a uniform distribution of legislative gains over all member states. Unanimity and majority voting rules steer the power to act by defining the number of feasible decisions, whereas various voting prerogatives, such as voting weights or single veto player positions, determine member states' chances to influence the outcome. Thus, only the combination of both aspects, (in-)equality and strength, can offer a satisfactory account for the member states' choice of EU voting rules.

Figure 2 combines the instruments measured by relative decisiveness $\phi$ and absolute inclusiveness $\omega$ of member states. For the study of specific constitutional choices, we take into account both aspects of member states' expectations of potential EU legislation. Accordingly, the choice of the strength of voting rules depends on the expected gains determined by the number of feasible decisions, whilst the distribution is regulated by equal or unequal settings. The member states' expectation of a few decisions by uniform distribution of EU legislative gains favours the setting of unanimity, whereas a higher number by uniform distribution results in unweighted majority voting. Member states may also agree on single veto player positions when they expect a low number of decisions but an asymmetric distribution of EU legislative gains. Finally, weighted votes may be introduced in the case of a higher number of decisions by asymmetric distribution.

Although our scheme considers the different voting rules within the Council, the question of the participation of supranational entities still remains. Studying the interaction between the Council, the Commission and the EP, recent applications of spatial models assumed extreme policy positions of supranational entities when determining the different procedural win sets (Steunenberg, 1994; Tsebelis, 1994; Schneider, 1995). Under this assumption, the participation of the Commission and the EP may bias mem ber states' legislative gains, prompting the question as to why some member 


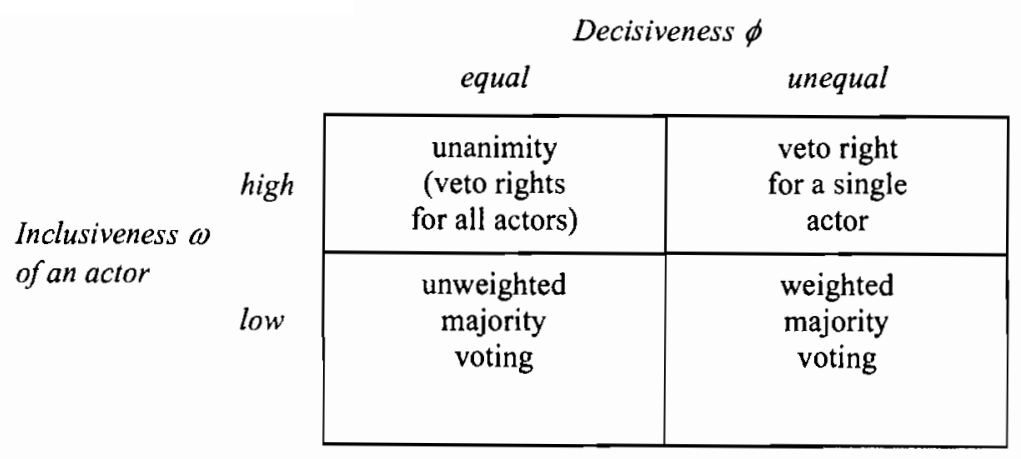

Figure 2, Characterisation of voting procedures

states should accept the restriction of their own legislative profits. Leaving aside the assumption of extreme policy positions of supranational entities, we argue that the Commission and the EP are expected to increase the gains of the member states by promising to reduce both transaction costs and the democratic deficit. Since different procedures exist for EU legislation, the application of decisiveness and inclusiveness provides an insight into the member states' expectations of different policy areas.

\section{Member states' expectations of policy area legislation}

The consequences of different provisions for the Commission, the member states and the political groups in the EP are listed in Table 1. For the reasons discussed, we measure relative decisiveness by means of the Shapley-Shubik index $\phi$ and absolute inclusiveness by means of our index $\omega$ defined above. In the rows of Table 1 we list the entities grouped along EU chambers. The columns refer to our procedures and three different rules which may be applied to the standard procedure. Each of the six procedural settings has distinct effects on entities' decisiveness and inclusiveness.

Under standard procedure, we find equal and unequal settings with varying voting quotas. Although decisiveness $\phi$ does not differentiate between the member states either in the case of unanimity (.0625) or simple majority (.0333), their degrees of inclusiveness $\omega$ reveal the greatest difference. Unanimity guarantees the inclusion of all member states' policy preferences indicated by their maximal inclusiveness of 1.0. In the case of simple majority, by contrast, the danger of being excluded is very high (.5500) approaching the dummy player's inclusion probability of 0.5 . All member states, howewer, have the same absolute and relative power on different levels. Under qualified majority in standard, Article 148, 2b, cooperation 


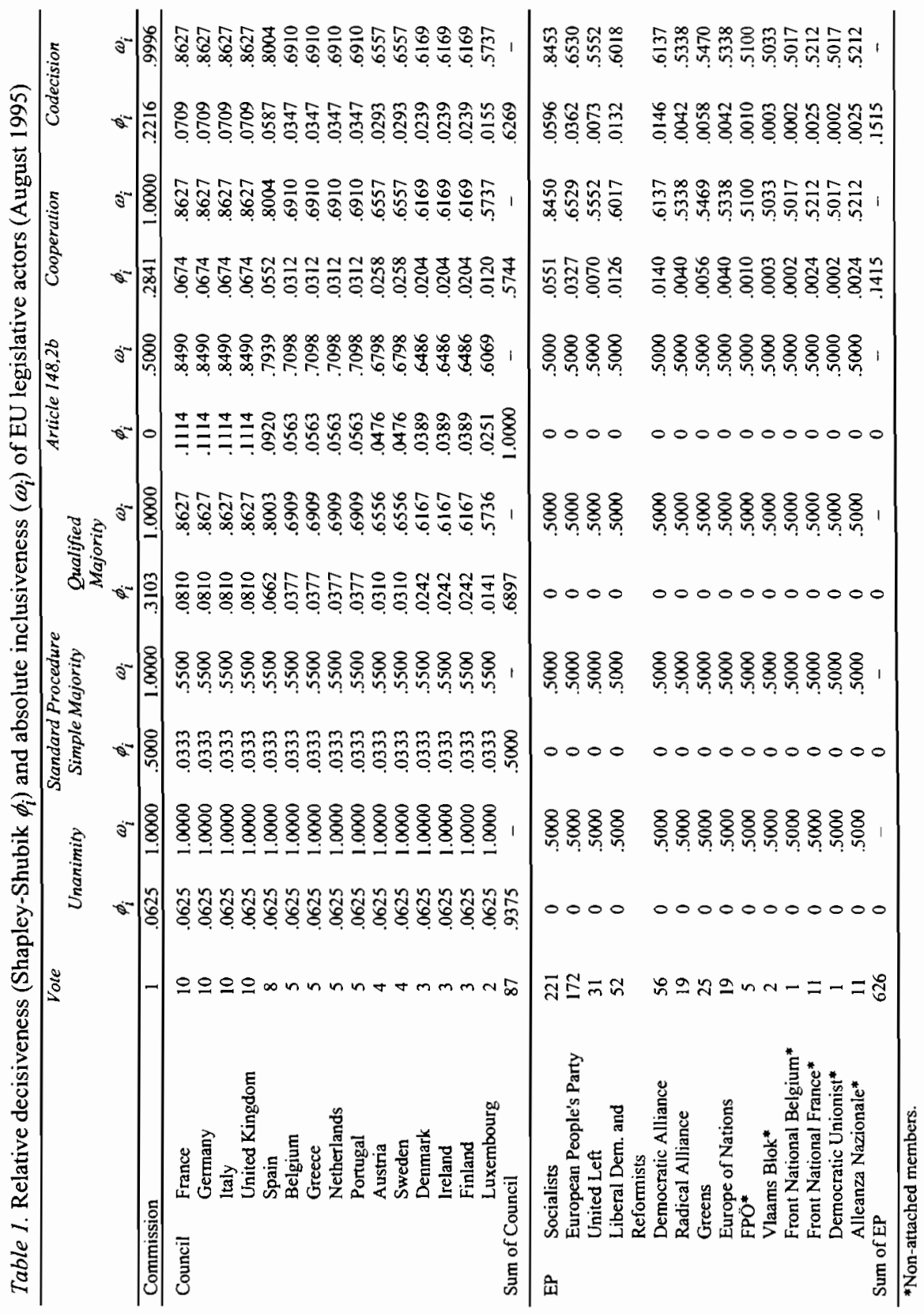


and codecision procedure the inclusion probability of the four large member states is $86 \%$ and $85 \%$, respectively, while Luxembourg's inclusiveness varies between $57 \%$ and $61 \%$. The relative decisiveness of large member states is also higher here than in cases of equal settings. Qualified majority thus stresses the differences between the member states with regard to relative decisiveness and absolute inclusiveness.

Concerning the inter-institutional interaction in the standard procedure, the EP is a dummy player and can be excluded from building any feasible winning coalition. Hence, the EP cannot influence the outcome and its policy preference is included only by luck. The feature of the bicameral setting is illustrated by the Commission's inclusiveness and decisiveness. Under standard procedure the Commission's policy preference must be included in any legislative proposal, but its ability of being decisive varies widely. The Commission is an equal counterpart to all member states in cases of simple majority voting, but its decisiveness decreases from majority voting to unanimity. Hence, if the member states take a unanimous decision, the Commission has the lowest share of relative power. Except for the unicameral procedure of Article 148, 2b, the Commission's policy preferences are included in all EU legislation. Qualified majority discriminates between the member states, and the additional provision for a minority rule (Article 148, $2 b)$ - the only unicameral procedure - not only favours the smaller member states' relative decisiveness but also increases their absolute inclusiveness.

Compared to qualified majority under standard procedure, the cooperation and codecision procedures have little effect on member states' inclusiveness. Only their decisiveness is modified as a result of the participation of the EP. However, the parliamentary entities' probability of being included in potential EU legislation increases substantially. Introducing the EP as a third collective actor is thus an instrument geared towards including another dimension into EU legislation without increasing the member states' probability of having their preferences disregarded. Comparing the cooperation and the codecision procedure, the latter strengthens the decisive role of the Council in particular.

Finally, the combination of relative decisiveness and absolute inclusiveness gives a satisfactory account for the member states' choice of institutional settings when they expect legislative gains from potential EU legislation in specific policy areas. Although the participation of supranational entities, such as the Commission or the EP, may promise higher gains, the member states' expectation of potential EU legislative costs prohibits the material integration of further policy areas. Material integration is thus a function of the expected effects of institutional settings. 
Table 2. Proportion of procedural settings by treaty eras (per cent)

\begin{tabular}{|c|c|c|c|c|c|c|c|c|c|c|c|c|}
\hline \multirow[b]{2}{*}{ EU Policy Area } & \multicolumn{3}{|c|}{$\begin{array}{l}\text { Treaty of Rome } \\
\text { (1958-87) }\end{array}$} & \multicolumn{4}{|c|}{$\begin{array}{c}\text { Single European Act } \\
(1987-93)\end{array}$} & \multicolumn{5}{|c|}{$\begin{array}{c}\text { Maastricht Treaty } \\
\text { (1993-) }\end{array}$} \\
\hline & $U$ & $Q$ & $S$ & $U$ & $Q$ & $S$ & $\mathrm{CO}$ & $U$ & $Q$ & $S$ & $\mathrm{CO}$ & $C D$ \\
\hline Principles/Citizenship & 60 & 40 & & 43 & 43 & & 14 & 67 & 22 & & & 11 \\
\hline $\begin{array}{l}\text { Free Movement of } \\
\text { Goods }\end{array}$ & 22 & 78 & & 12 & 88 & & & 12 & 88 & & & \\
\hline Agriculture & 17 & 83 & & 17 & 83 & & & I7 & 83 & & & \\
\hline $\begin{array}{l}\text { Free Movement of } \\
\text { Persons, Service, } \\
\text { Capital }\end{array}$ & 47 & 53 & & 33 & 39 & & 28 & 33 & 43 & & & 24 \\
\hline Transport & 67 & 33 & & 50 & 50 & & & 50 & 17 & & 33 & \\
\hline Common Rules & 43 & 57 & & 30 & 50 & & 20 & 31 & 54 & & & 15 \\
\hline $\begin{array}{l}\text { Economic Policy } \\
\text { Trade }\end{array}$ & 20 & $\begin{array}{c}80 \\
100\end{array}$ & & 20 & $\begin{array}{c}80 \\
100\end{array}$ & & & 17 & $\begin{array}{c}58 \\
100\end{array}$ & & 25 & \\
\hline Social Policy & 40 & 40 & 20 & 33 & 33 & 17 & 17 & 25 & & & 50 & 25 \\
\hline Culture & & & & & & & & & & & & 100 \\
\hline Public Health & & & & & & & & & & & & 100 \\
\hline Consumer Protection & & & & & & & & & & & & 100 \\
\hline Transeuropean & & & & & & & & & & & 50 & 50 \\
\hline Networks & & & & & & & & & & & & \\
\hline Industry Policy & & & & & & & & 100 & & & & \\
\hline $\begin{array}{l}\text { Economic and Social } \\
\text { Cohesion }\end{array}$ & & & & 25 & 50 & & 25 & 40 & 20 & & 40 & \\
\hline Research and & & & & 50 & & & 50 & 25 & 25 & & 25 & 25 \\
\hline $\begin{array}{l}\text { Technical } \\
\text { Development }\end{array}$ & & & & & & & & & & & & \\
\hline Environment & & & & 100 & & & & 33 & & & 33 & 33 \\
\hline Development & & & & & & & & & & & 100 & \\
\hline Association & 100 & & & 100 & & & & 100 & & & & \\
\hline Institutional & 100 & & & 100 & & & & 100 & & & & \\
\hline Financial Provisions & 50 & 50 & & 45 & 55 & & & 33 & 67 & & & \\
\hline Final Provisions & 80 & 20 & & 80 & 20 & & & 80 & 20 & & & \\
\hline $\begin{array}{l}\text { Sum per Era } \\
(100 \text { per cent })\end{array}$ & 51 & 48 & 1 & 45 & 45 & 1 & 9 & 38 & 38 & & 12 & 11 \\
\hline
\end{tabular}

U-Unanimity, Q-Qualified Majority, S-Simple Majority under Standard Procedure; COCooperation Procedure; CD-Codecision Procedure.

Source. Compilation of own data, see König (1997).

The selective application of procedural settings to EU policy areas may serve as an indicator for the specific gains member states expect from EU legislation. Not only do EU voting rules vary in the degree of inclusiveness and decisiveness, but even more to the point the provisions for EU legislation have been changed quite differently and discriminate even within policy areas. Table 2 lists the proportion of procedural settings for all EU policy areas that came into operation with the Treaty of Rome in 1958, the Single 
European Act in 1987 and the Maastricht Treaty in 1993. As the table indicates, the policy areas of agriculture, trade, association, institutional and final provisions have been excepted from constitutional modifications. Changes of the status quo in the areas of association, institutional and final provisions concern the core of the EU framework. When negotiating on the Rome Treaty, member states being in fear of many (unfavourable) decisions therefore preferred unanimity as the principle voting rule in these fields. By contrast, the policy areas of agriculture and trade are dominated by the provision of qualified majority rules with voting weights under standard procedure. According to our two aspects of constitutional choice, member states originally expected an asymmetric distribution of a higher number of $\mathrm{EU}$ decisions with additional gains by the Commission's role in reducing transaction costs. For both policy areas, characterised by the highest numbers of proposals and adoptions (König, 1997, 86), member states have abstained from reducing the democratic deficit by excluding the EP.

In comparison, numerous modifications have been made in the areas of free movement, traffic, common rules and social policy which encompass the participation of the EP. The introduction of the cooperation procedure has also contributed to the reduction of the proportion of qualified and unanimous provisions. We observe a similar pattern for the introduction of the codecision procedure. Except for environmental policies, the codecision procedure has replaced the former provision for the cooperation procedure. Again, the recent introduction of industry policy does not promise EU legislative gains by a high number of decisions which would pave the way for weaker voting rules, whereas other areas introduced by the Maastricht Treaty provide for qualified majorities. In sum, different procedures and different voting rules regulate most EU policy areas. Our findings show a tendency towards weighted qualified majority voting in the Council either by modifications to the standard procedure or by the introduction of the cooperation and codecision procedures. Despite this overall tendency, the member states have increased the proportion of unanimous voting rules in some policy areas, namely in the areas of the common rules and economic and social cohesion.

\section{Conclusion}

Looking beyond the scope of the analysis here, the Maastricht Treaty has brought about a new pattern of EU institutional integration. This new form of integration describes the move to selective expectations of potential legislative costs. It can be observed in the recent trend of including provisions for "opt-out" clauses as often favoured by either the United Kingdom or 
Denmark. The tendency towards this new pattern of selective EU integration has been reinforced in the provisions laid down for Monetary Union, as is fittingly illustrated by the current debate on the economic criteria for membership. Although enlargement by Eastern and Southern countries has rekindled the debate on core-membership, recent constitutional development has been characterised by the constitutional choice of voting rules applicable to all member states.

For the analysis of recent EU constitutional development we presented our approach on constitutional actors' expectation of legislative gains that could be obtained by the introduction or change of voting rules. In our view, the impact of voting rules on future decision making can be expressed by two aspects, the strength and the (in-)equality of their settings. Due to the fact that relative voting power analyses cannot consider the strength of voting rules, we introduced our concept of inclusiveness measuring the frequency with which an actor will participate in winning coalitions in relation to the number of all winning coalitions. Since high inclusiveness of all actors results in high status quo probability, inclusiveness directly addresses one aspect of legislative gains, namely the number of feasible coalitions in which an actor can realise his preference.

However, the second aspect of legislative gains concerns their distribution among actors. In order to steer the distribution of expected legislative gains, constitutional actors may establish either equal or unequal settings, the latter privileging some actors by providing different voting weights or actorspecific veto rights. Their effects can be measured by means of the ShapleyShubik index which calculates actors' relative abilities of being decisive in forming winning coalitions. In the case of the equal "One-Man-One-Vote" provision, actors are provided with the same relative ability to influence the distribution of expected legislative gains, while unequal provisions introduce actor-specific prerogatives.

The reason for the establishment of unequal settings might be that all constitutional actors agree to balance the distribution of gains when certain actors are considered to have a higher status quo bias. In the past, constitutional actors favoured a common solution rather than allowing for coremembership. Core-membership, however, has already been applied to EU social politics and Monetary Union. According to our approach, there might be two reasons for core-membership: either EU core-membership provides for even higher expected gains or constitutional actors could not agree on a formula for balancing the distribution of gains. 


\section{References}

Achen, C.H. (1995), "How Can We Tell a Unitary Rational Actor when We See One?", Paper prepared for presentation at the annual meeting of the Midwest Political Science Association, Chicago.

Attina, F. (1990), "The Voting Behavior of the European Parliament Members and the Problem of Europarties", European Journal of Political Research, 5, 557-79.

Barry, B. (1989), Theories of Justice. A Treatise on Social Justice, London: HarvesterWheatsheaf.

Banzhaf, J.F. (1965), "Weighted Voting Doesn't Work: A Mathematical Analysis", Rutgers Law Review, 19, 317-43.

Brams, S.J. (1975), Game Theory and Politics, New York: Free Press.

Brams, S.J. (1976), Paradoxes in Politics, New York: Free Press.

Brams, S.J., and P. Affuso (1985), "New Paradoxes of Voting Power on the EC Council of Ministers", Electoral Studies, 4, 135-9.

Bräuninger, T. (1996), Die Modellierung von Entscheidungsverfahren internationaler Organisationen am Beispiel der Meeresbodenbehörde. Teilnahme-, Mitwirkungs- und Durchsetzungschancen in einem institutionalisierten Regime (unpublished thesis), Mannheim: University of Mannheim.

Buchanan, J.M., and G. Tullock (1962), The Calculus of Consent: Logical Foundations of Constitutional Democracy, Ann Arbor: University of Michigan Press.

Coleman, J.S. (1971), "Control of Collectivities and the Power of a Collectivity to Act", in: B. Lieberman (ed.), Social Choice, New York: Gordon and Breach, 269-99.

Dubey, P., and L.S. Shapley (1979), "Mathematical Properties of the Banzhaf Power Index", Mathematics of Operations Research, 4, 99-131.

Fischer, D., and A. Schotter (1978), "The Inevitability of the Paradox of Redistribution in the Allocation of Voting Weights", Public Choice, 33, 49-67.

Garrett, G., and G. Tsebelis (1996), "An Institutional Critique of Intergovernmentalism", International Organization, 50, 269-99.

Garrett, G., I. McLean, and M. Machover (1995), "Power, Power Indices and Blocking Power: A Comment on Johnston", British Journal of Political Science, 25, 563-68.

Hosli, M.O. (1993), "Admission of European Free Trade Association States to the European Community: Effects on Voting Power in the European Community Council of Ministers", International Organization, 47, 629-43.

Jacobs, F., R. Corbett, and M. Shackleton (1992), The European Parliament, London: Longman.

Johnston, M. (1994), The European Council, Oxford: Westview.

Johnston, R.J. (1995), "The Conflict over Qualified Majority Voting in the European Union Council of Ministers: An Analysis of the UK Negotiating Stance Using Power Indices", British Journal of Political Science, 25, 245-88.

Koehler, D.H. (1990), "The Size of the Yolk: Computations of Odd and Even-Numbered Committees", Social Choice and Welfare, 7, 231-45.

König, T. (1997), Europa auf dem Weg zum Mehrheitssystem?, Gründe und Konsequenzen nationaler und parlamentarischer Integration, Opladen: Westdeutscher Verlag.

König, T., and T. Bräuninger (1996), "Power and Political Coordination in America and German Multi-chamber Legislation", Journal of Theoretical Politics, 8, 331-60.

König, T., and T. Bräuninger (1998), "The Inclusiveness of European Decision Rules", Journal of Theoretical Politics, 10, 125-41.

Lane, J.-E., R. Mæland, and S. Berg (1995), "The EU Parliament: Seats, States and Political Parties", Journal of Theoretical Politics, 7, 395-400. 
Ludlow, P. (1991), "The European Commission", in: R.O. Keohane, and S. Hoffman (eds.), The New European Community: Decisionmaking and Institutional Change, Boulder, Col.: Westview, 85-132.

McKelvey, R. (1979), "General Conditions for Global Intransitivities in Formal Voting Models", Econometrica, 47, 1085-112.

Nurmi, H. (1987), Comparing Voting Systems, Dordrecht: Reidel Publishing.

Schneider, G. (1995), "The Limits of Self-Reform: Institution-Building in the European Union", European Journal of International Relations, 1, 59-86.

Shapley, L.S, and M. Shubik (1954), "A Method for Evaluating the Distribution of Power in a Committee System", American Political Science Review, 48, 787-92.

Shelley, F.M. (1986), "Voting Power in Municipal Annexation Elections", Quality and Quantity, 120, 257-60.

Spence, D. (1994), "Structure, Functions and Procedures in the Commission", in: G. Edwards, and D. Spence (eds.), The European Commission, Essex: Longman, 92-116.

Steunenberg, B. (1994), "Decision Making Under Different Institutional Arrangements: Legislation by the European Community", Journal of Institutional and Theoretical Economics, 150, 642-69.

Tsebelis, G. (1994), "The Power of the European Parliament as a Conditional Agenda Setter", American Political Science Review, 88, 128-42.

Usher, J. (1994), "The Commission and the Law", in: G. Edwards, and D. Spence (eds.), The European Commission, Essex: Longman, 146-68.

Wessels, W. (1991), "The EC Council: The Community's Decisionmaking Center", in: R.O. Keohane, and S. Hoffman (eds.), The New European Community: Decisionmaking and Institutional Change, Boulder, Col.: Westview, 133-54.

Westlake, M. (1994), The Commission and the Parliament, London: Butterworths.

Widgrén, M. (1994), "Voting Power in the EC Decision-Making and the Consequences of Two Different Enlargements", European Economic Review, 38, 1153-70. 